\title{
Long-term mean annual microphytobenthos chlorophyll a variation correlates with air temperature
}

\author{
Victor N. de Jonge ${ }^{1, *}$, Willem F. de Boer ${ }^{2,5}$, Dick J. de Jong ${ }^{3}$, Verena S. Brauer ${ }^{4}$ \\ ${ }^{1}$ Institute of Estuarine and Coastal Studies (IECS), University of Hull, HU6 7RX Hull, UK \\ ${ }^{2}$ Koeman and Bijkerk, Postbus 14, 9750 AA, Haren, The Netherlands \\ ${ }^{3}$ Rijkswaterstaat Directorate Zeeland, Poelendaelesingel 18, 4335JA Middelburg, The Netherlands \\ ${ }^{4}$ Laboratoire Ecologie des Systèmes Marins Côtiers ECOSYM, UMR 5119, CNRS, IRD, Ifremer, Université Montpellier 2 , \\ Place E. Bataillon, 34095 Montpellier Cedex 05, France \\ ${ }^{5}$ Present address: Resource Ecology Group, Wageningen University, Droevendaalsesteeg 3a, 6708 PB, Wageningen, \\ The Netherlands
}

\begin{abstract}
Long-term interannual variations in the mean microphytobenthos chlorophyll $a$ ( $\mathrm{chl} \mathrm{a)} \mathrm{of} \mathrm{the} \mathrm{Ems} \mathrm{estuary} \mathrm{were} \mathrm{investigated.} \mathrm{Concentrations} \mathrm{in} \mathrm{the} \mathrm{1990s} \mathrm{were} \mathrm{on} \mathrm{average} 1.5$ times higher than during the period from 1976 to 1978, but a trend in chl a over the entire period (1976 to 1999) was not found. In agreement with findings from the late $1970 \mathrm{~s}$, the mean chl $a$ concentrations over the post 1990 period correlated significantly with the station elevation related exposure time. Over the entire 1976 to 1999 study period, the estuary mean annual chl a concentrations correlated strongly and significantly with the mean annual air temperature. Although the range of the variation in the mean annual air temperature of the studied years was only 7.5 to $10.2^{\circ} \mathrm{C}$, it surprisingly corresponded with a ca. 2.5 -fold variation in the mean annual microphytobenthos chl a. In addition to chl a, mean monthly C:chl a ratios from 1976 to 1977 also correlated positively with changes in temperature. Microphytobenthos carbon biomass [chl $a \times(\mathrm{C}: \mathrm{chl} a)]$ may, therefore, respond even stronger to air temperature than chl a does. The correlations are most likely a combination of direct temperature effects on microphytobenthos and stronger, probably complex, indirect temperature effects on the seasonal development and standing stock of young and adult grazers (bivalves) and their carnivores like the brown shrimp Crangon crangon.
\end{abstract}

KEY WORDS: Benthic diatoms · Long-term temperature effect · Carbon: chlorophyll a ratio Resale or republication not permitted without written consent of the publisher

\section{INTRODUCTION}

Microphytobenthos contributes significantly to the total system primary production in tidal flat estuaries and other shallow coastal systems (Colijn \& de Jonge 1984, de Jonge 1995a, MacIntyre et al. 1996, Cahoon 1999, 2006, Underwood \& Kromkamp 1999, Baird et al. 2004). These microalgae, mainly pennate diatoms, live at or near the sediment surface, where they produce organic material predominantly during low tide when they are exposed. During high tide, a varying part of the microphytobenthos can become resuspended in the water column by the scouring effect of wind-induced waves (de Jonge 1985, de Jonge \& van Beusekom 1995, Koh et al. 2006). The importance of this phenomenon depends on the elevation of the intertidal flats in relation to the local tidal characteristics. Once resuspended, the tidal currents transport the diatoms between the submersed intertidal flats and the channels, during which they are mixed with other water masses and redistributed (de Jonge \& van Beusekom 1995). When resuspended, these 
microalgae, interestingly, continue to contribute to the primary production in the water column (V. N. de Jonge and $\mathrm{H}$. Peletier unpubl. experimental results).

The system-wide contribution of the microphytobenthos (benthic plus resuspended) to the total primary production is variable, but can, as established for the Ems estuary with $\sim 50 \%$ intertidal flats, be as high as that of the 'real' phytoplankton (de Jonge 1995a). The estuary-wide microphytobenthos chlorophyll a ( $\mathrm{chl} \mathrm{a}$ ) mass in the top $2 \mathrm{~cm}$ of the sediment can easily exceed the chl a mass in the water (de Jonge 1995a). There is clear evidence that microphytobenthos supports the benthic food web (Decho \& Fleeger 1988, Hecky \& Hesslein 1995, Herman et al. 2000, Middelburg et al. 2000, Moncreiff \& Sullivan 2001) and that it is an important food source for certain benthic fauna species (e.g. Hummel 1985, Kamermans 1994) as well as pelagic copepods (de Jonge \& van Beusekom 1992). This all indicates that these benthic microalgae play a pivotal role for the functioning of estuarine systems in general.

The primary factors that regulate microphytobenthos production and biomass are typically light and nutrients. Yet, during the investigation period, the nutrient concentrations in most of the water column and in the sediments of the Ems estuary were most likely not growth-limiting (de Jonge 1995b, 2000), a phenomenon that has been observed in many of the western European systems (de Jong et al. 1994, Brotas et al. 1995, Barranguet et al. 1998). In contrast, the underwater light conditions were and still are strongly growth-limiting for phytoplankton in most of the Ems estuary (Colijn 1982, 1983, de Jonge 1983, 2000, van Beusekom \& de Jonge 1998), which increases the importance of microphytobenthos for the primary production of the entire ecosystem. For the intertidal flats, the light climate during submersion is determined by the ambient irradiance in combination with water turbidity, which is partly controlled by wind and wave action (de Jonge 1995a, de Jonge \& van Beusekom 1995), and water depth. During low tide, the light climate of the intertidal flats is determined by weather and season in combination with the elevation of the intertidal flat and the tidal phase, which together determine the exposure time of the sediment surface (see also Colijn \& de Jonge 1984). Apart from environmental factors, the microphytobenthos primary production is also determined by its packing density. Blanchard et al. (2001, 2002, 2006, Herlory et al. 2004) found that a net primary production only occurred when the chl a concentrations in the top $1 \mathrm{~cm}$ sediment layer were lower than $\sim 160$ to $170 \mathrm{mg} \mathrm{m}^{-2}$. Higher chl a densities mostly resulted in net algal res- piration, which was ascribed to a limitation of inorganic carbon or nutrients (Admiraal et al. 1982, Cook et al. 2010) or severe light limitation. Also, biotic factors, like grazing, influence standing stock and primary production of the microphytobenthos. Since the interactions between all the above mentioned physico-chemical, physical and biological factors lead to complicated and interwoven 'bottom-up' and 'topdown' controls, it is not a straightforward process to determine the causes of measured variations in chl a in coastal systems (see de Jonge \& Essink 1991).

Despite these problems and shortcomings, much is known and there is data available to qualitatively asses within year dynamics of microphytobenthos chl a. This is, however, not so for longer term (interannual) variations. Given the ongoing debate on the possible impact of climate change at all ecosystem levels, an interesting question is to what extent temperature may determine interannual chl $a$ and related organic carbon biomass variations of the microphytobenthos and how this in turn affects the total food web.

The role of many factors involved in the seasonal regulation of the microphytobenthos growth and standing stock in the field has been clarified in some detail in the past, except for the effect of temperature. Therefore, in the present paper, we focus on possible temperature effects in relation to $\mathrm{chl}$ a mass variations, using data from the Ems estuary.

The role of nutrients (Admiraal 1977a, Colijn 1983, Helder 1983), light (Colijn \& van Buurt 1975, Admiraal \& Peletier 1980, Colijn 1982), system residence time (Helder \& Ruardij 1982), interaction between tidal flats and water (de Jonge 1995a, de Jonge \& van Beusekom 1995) and estuarine transport and exchange processes (Baretta \& Ruardij 1988) have all been investigated and discussed at a system-wide scale for the Ems estuary. The overall conclusion was that light (and consequently elevation; see Colijn \& de Jonge 1984, de Jonge \& Colijn 1994) was the most important determinant for the available chl $a$ and primary production of microphytobenthos and phytoplankton.

In short-term experimental investigations, Blanchard et al. (1997, 2001), Colijn \& van Buurt (1975) and Admiraal (1977b) studied algal growth in relation to temperature. The latter 2 teams experimentally demonstrated a clear temperature effect on the growth of benthic diatoms, while Admiraal \& Peletier (1980) found the same for developing natural benthic diatom films in microcosms under field conditions. Despite this research, up to now no clear effect of temperature on the chl a (or carbon biomass) of the 


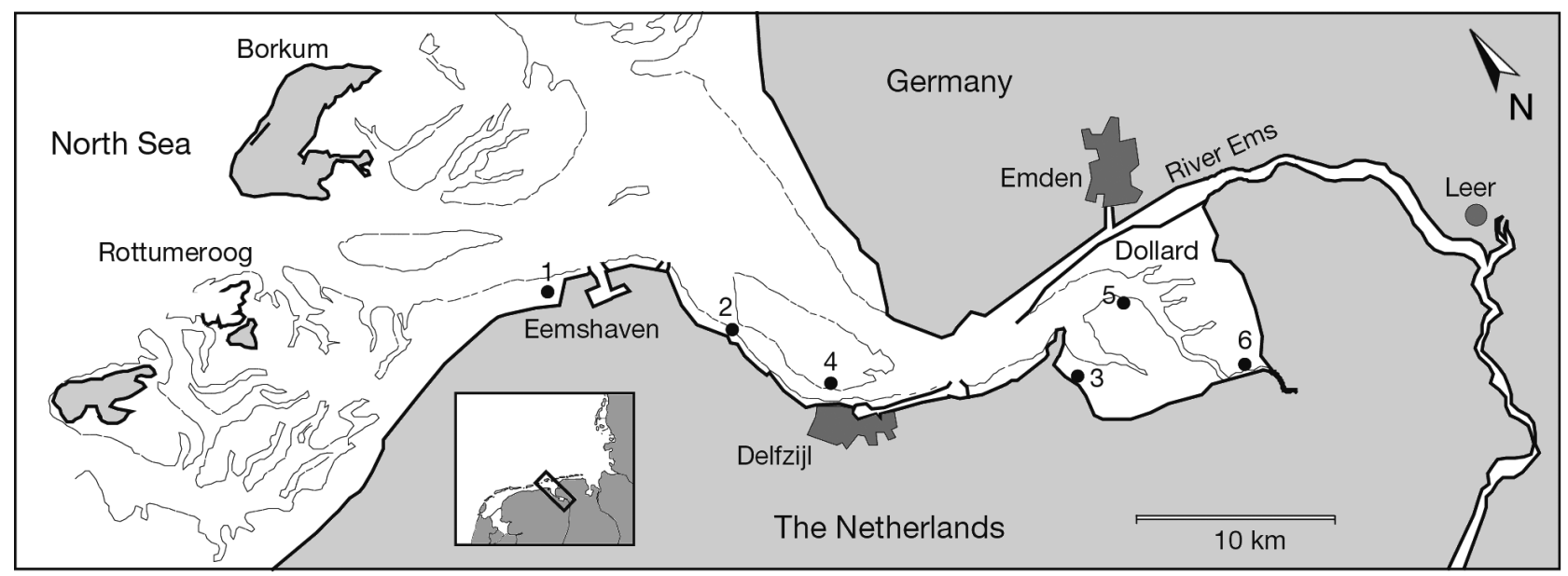

Fig. 1. The Ems Estuary with the 6 stations sampled over the periods 1976-1978 and 1992-1999. For more details see Google http://earth.google.com, Wadden Sea area in the northeastern part of the Netherlands

microphytobenthos was detected when considering field data.

The main focus of the present paper is to test whether there is a relationship between temperature and long-term variation in the mean microphytobenthos chl a content of the sediment in the Ems estuary and to discuss the possible implications of such a relationship. This is especially interesting as the temperatures in western Europe are rising faster than elsewhere on earth (van Oldenborgh et al. 2008).

\section{MATERIALS AND METHODS}

\section{Study area}

The Ems estuary (Fig. 1) is a coastal plain estuary, which crosses the Wadden Sea at the border between the Netherlands and Germany. Excluding the outer delta and including the freshwater tidal river, the surface area covers $\sim 475 \mathrm{~km}^{2}$. The length of the estuary is $\sim 70 \mathrm{~km}$ and, including the freshwater tidal river, the total length is $\sim 100 \mathrm{~km}$. Approximately $40 \%$ of the lower reaches (the area seaward of Stn 2 in Fig. 1) and as much as $80 \%$ of the Dollard (Fig. 1) comprise intertidal flats. The tidal prism of the estuary at the inlet is $\sim 10^{9} \mathrm{~m}^{3}$ (de Jonge 1992a). The tidal range varies from $\sim 2.3 \mathrm{~m}$ in the tidal inlet to over $3.0 \mathrm{~m}$ near Delfzijl and Emden.

\section{Sampling stations}

Microphytobenthos in the Ems estuary has been studied for many years with the aim of modelling the ecosystem functioning dynamics (Baretta \& Ruardij 1988). Within this context, a sampling scheme was developed based on the system's bathymetry and physical features. In 1992, Rijkswaterstaat started microphytobenthos monitoring at the 6 locations in the Ems estuary (Fig. 1) which had been previously sampled (de Jonge \& Colijn 1994).

\section{Sampling}

The corer based sampling procedure used from 1976 to 1978 has been described by de Jonge \& Colijn (1994). Sampling was always done with a perspex core of $2.4 \mathrm{~cm}$ inner diameter. During 1992 and 1994 to 1999 , the monthly samples were taken with a comparable corer. Three substations per sampling station (consisting of a $500 \times 500 \mathrm{~m}$ quadrat) were selected for sampling the elevation gradient. Based on the detailed study results from 1972 to 1986 (e.g. van Es 1982, Colijn 1983, de Jonge 1992b), 5 cores were taken at every substation in a circle to arrive at a representative pigment value per station. The cores were sliced and the upper $0.5 \mathrm{~cm}$ of the 5 cores pooled by substation for chl $a$ analysis. Samples were stored at $-30^{\circ} \mathrm{C}$ and lyophilized before extraction in $90 \%$ acetone.

\section{Chl $a$ analysis and conversions}

From 1976 to 1978 (the 'pre-1990 period'), chl a was determined spectrophotometrically. Concentrations were expressed in weight per unit surface area $\left(\mathrm{mg} \mathrm{m}^{-2}\right)$ for the top $0.5 \mathrm{~cm}$ sediment layer. Pigment concentrations were measured using a modification 
(addition of $60 \mu \mathrm{l}$ of $10 \% \mathrm{HCl}_{\text {; }}$ Moed \& Hallegraeff 1978) of Lorenzen's method (1967) and an overnight extraction time at $4^{\circ} \mathrm{C}$. During 1992 and 1994 to 1999 ('post-1990 period'), the sediment was sampled by comparable corers as above and again using an overnight period to extract the chl $a$, after which measurements were carried out by HPLC as described by Daemen (1986). The chl a values were expressed as a content on a weight per dry weight basis $\left(\mu \mathrm{g} \mathrm{g}^{-1}\right)$ for the top $0.5 \mathrm{~cm}$ sediment layer. The HPLC derived values are on average $~ 70 \%$ the values derived with the spectrophotometrical method of Lorenzen (Daemen 1986). To make the data of the entire 1976 to 1999 set mutually comparable and consistent with most of the literature, all data were converted to concentrations as measured by Lorenzen's method. Conversion was done by multiplying the HPLC values with a factor 1.43 (based on Daemen 1986). The conversion from weight per weight (of the post-1990 data) to weight per $\mathrm{m}^{2}$ was based on the specific density of the sediment at the 6 stations. These values were obtained during a full sedimentological analysis by D. J. de Jong (unpubl.) and carried out in 1992 and 1994. The effect of increasing mud content on the specific density of the sediment is illustrated in Fig. 2. The total range covers 0.63 to $1.69 \mathrm{~g} \mathrm{~cm}^{-3}$ and shows that the muddier the sediment is, the lower its specific density will be. The sediments with the lowest mud content (Stns 1 and 5) usually do not reach the mud content of the more muddy stations (Stns 4,2 and 6). This means that, despite the variation in values, the gradient in Fig. 2 is a persistent one. There was unfortunately no data to illustrate any available seasonal effect.

\section{Environmental factors}

Seasonal effects of environmental conditions and biotic interactions have been investigated before on a seasonal basis and were also incorporated in the ecosystem model of the Ems estuary (Baretta \& Ruardij, 1988). This, however, does not hold for longer term interannual variations. To find an explanation for long temporal scale related variations in chl a concentrations among stations and years, the effect of station elevation, irradiance, turbidity (Suspended Matter concentration = SPM), wind speed and air temperature were investigated for the post1990 period. The quality of the data on water temperature was too low to be used. This was due to the fact that water temperatures were only measured during water sampling. The elevations of the different sta- tions and substations were derived from soundings carried out in the 1990s by Rijkswaterstaat. SPM data was obtained from the Rijkswaterstaat DONAR monitoring database. Data on air temperature, irradiance and wind speed were obtained from the KNMI (Royal Netherlands Meteorological Institute). Mean meteorological conditions were calculated based on 3 meteorological stations close to the coast in the study area (Lauwersoog, Eelde and Nieuw Beerta).

For the pre-1990 period environmental data were not available in the required detail for the above mentioned meteorological stations, so only mean annual air temperatures and mean annual chl a values were used. The post-1990 data on mean annual air temperature and mean annual chl $a$ and the same data from the pre-1990 period (the years 1976 to 1978 from de Jonge \& Colijn 1994) were combined to investigate the relationship between air temperature and $\operatorname{chl} a$.

\section{C:chl a ratios}

In addition to chl $a$, an existing data set on C:chl $a$ ratios from 1976 to 1978 (de Jonge 1980) was reanalysed to investigate the possible effect of air temperature (Table 1). In de Jonge 1980, temperature was not considered as a possible relevant factor explaining the observed seasonal fluctuations in $\mathrm{C}$ : chl a ratios. De Jonge (1980) concluded that C:chl a varied seasonally per sampling period and that there were no spatial, i.e. no among-stations differences in $\mathrm{C}: \mathrm{chl}$ a. Therefore, for the present paper, data from all 6 stations were pooled and the monthly mean $\mathrm{C}: \mathrm{chl}$ a ratios calculated. The aim was to investigate whether the variation in the monthly mean C:chl $a$ ratios correlated with air temperature. If so, then that result could be used to indicate to what extent any

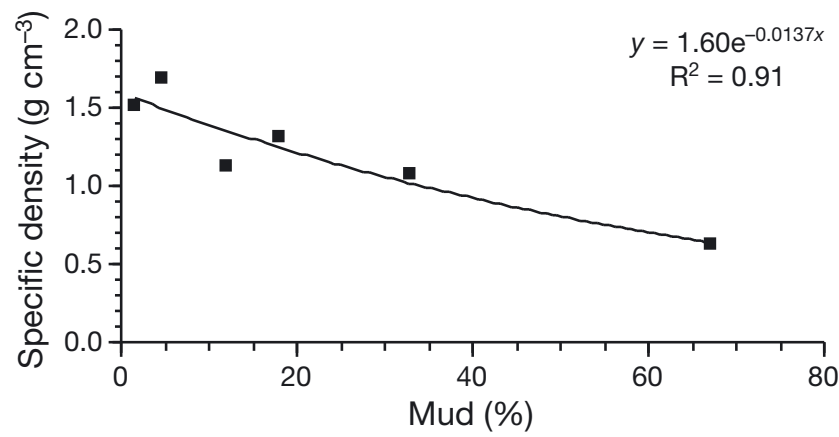

Fig. 2. Specific density of the sediment at the 6 stations against the mud content of the sediment, to illustrate the effect of the variations in mud content. See Fig 1 for station locations 
Table 1. Description of the different data subsets used. Chl a: chlorophyll a

\begin{tabular}{|c|c|c|c|c|}
\hline Set & Year & No. & Description & Source \\
\hline $1 \mathrm{a}$ & $1992,1994-1999$ & 3493 & Raw data & This study \\
\hline $1 b$ & & 1135 & Stn mean per sampling date & This study \\
\hline $1 \mathrm{c}$ & & 412 & Stn mean per mo & This study \\
\hline $1 d$ & & 41 & Stn mean per yr & This study \\
\hline 2 & $\begin{array}{r}1976-1978 \\
1992-1999\end{array}$ & 12 & Estuary-wide mean per yr & $\begin{array}{r}\text { de Jonge \& Colijn } \\
(1994) \text {, this study }\end{array}$ \\
\hline 3 & 1976-1977 & 23 & $\begin{array}{l}\text { Estuary-wide mean C:chl } a \\
\text { per mo }\end{array}$ & This study ${ }^{a}$ \\
\hline \multicolumn{5}{|c|}{${ }^{\mathrm{a} C} \mathrm{C}$ chl a ratios from de Jonge (1980) } \\
\hline
\end{tabular}

temperature related variation in C:chl a could contribute to a possible accumulated temperature effect via both chl $a$ and $C: c h l ~ a$ on the microphytobenthos carbon biomass [expressed as chl $a \times(\mathrm{C}: \mathrm{chl} a)]$.

\section{Data sets}

The data sets in this paper were derived from different sources, yielding different data sub-sets, except for mean annual chl a and mean annual air temperature. Table 1 provides an overview of the structure of the data sets used.

\section{Statistical analyses}

The chl a data for the top $0.5 \mathrm{~cm}$ sediment layer did not follow a normal distribution. To satisfy the requirements for the application of parametric tests (Zar 1984), the data were log-transformed. To test whether data from substations could be used as independent data in the analysis, the spatial autocorrelation was calculated, using Moran's I test (R Development Core Team 2007). A General Linear Model (GLM) was applied to test for differences between the means among Station (Stn), Year (Yr) and Month (Mo), followed by the Tukey multiple comparison test to determine the differences between the classes. The $\eta^{2}$ statistic was used to describe the proportion of the total variation that is attributable to a specific predictor variable. The possible relationships between chl a concentrations and independent variables, such as air temperature, were tested using Spearman correlation tests and a multiple backward regression. The calculation of the independent contribution of each variable to the total explained variance of the regression model was carried out using hierarchical partitioning (Chevan \& Sutherland 1991).
The chl a data series in the post1990 period $(1992,1994$ to 1999) were often incomplete. If this happened, the data were case wise deleted. All statistical analyses were carried out in SPSS 15.0, except for the calculations of the spatial autocorrelation and the hierarchical partitioning, which were carried out in R (R Development Core Team 2007).

\section{RESULTS}

\section{Factors explaining spatial and temporal changes in chl a}

Spatial autocorrelation of substations

As a first step, we determined whether the data collected at the 3 substations within each station were independent, by calculating the spatial autocorrelation. The chl a concentrations of the 3 substations were spatially autocorrelated in all cases (Moran's $I=$ 0.088, $\mathrm{p}<0.001$ ). The data from substations were, therefore, pooled, using the mean chl a concentrations per station for further analysis.

\section{Trends}

The mean monthly chl a concentrations for the 6 stations in 1992, and 1994 to 1999 (Fig. 3) show strong variation among Stns, mo and $\mathrm{yr}$, without a visually clear seasonal pattern. A 3-way ANOVA (data set 1c in Table 1) with Stn, Yr and Mo as independent factors revealed significant effects of all 3 factors and their 2-way interaction terms, and explained $75 \%$ of the observed variation (Table 2 ). The factor yr had a significant effect on the mean chl a concentration with the highest $\eta^{2}$ of the 3 main factors (Table 2), with significantly higher values in 1992 and 1999 and lower values in 1996 (Tukey test, p < 0.05). Stn and mo were also significant, with lower chl a concentrations measured at Stn 3 and 4, and between December and March, and higher values reported at Stn 6, and between May and October (see also Fig. 3). Interannual and seasonal effects were apparent with a high $\eta^{2}(0.601)$ for the $\mathrm{Yr} \times$ Mo interaction term (Table 2).

A distinct pattern, however, emerged when the mean, log-transformed annual chl a values per sta- 

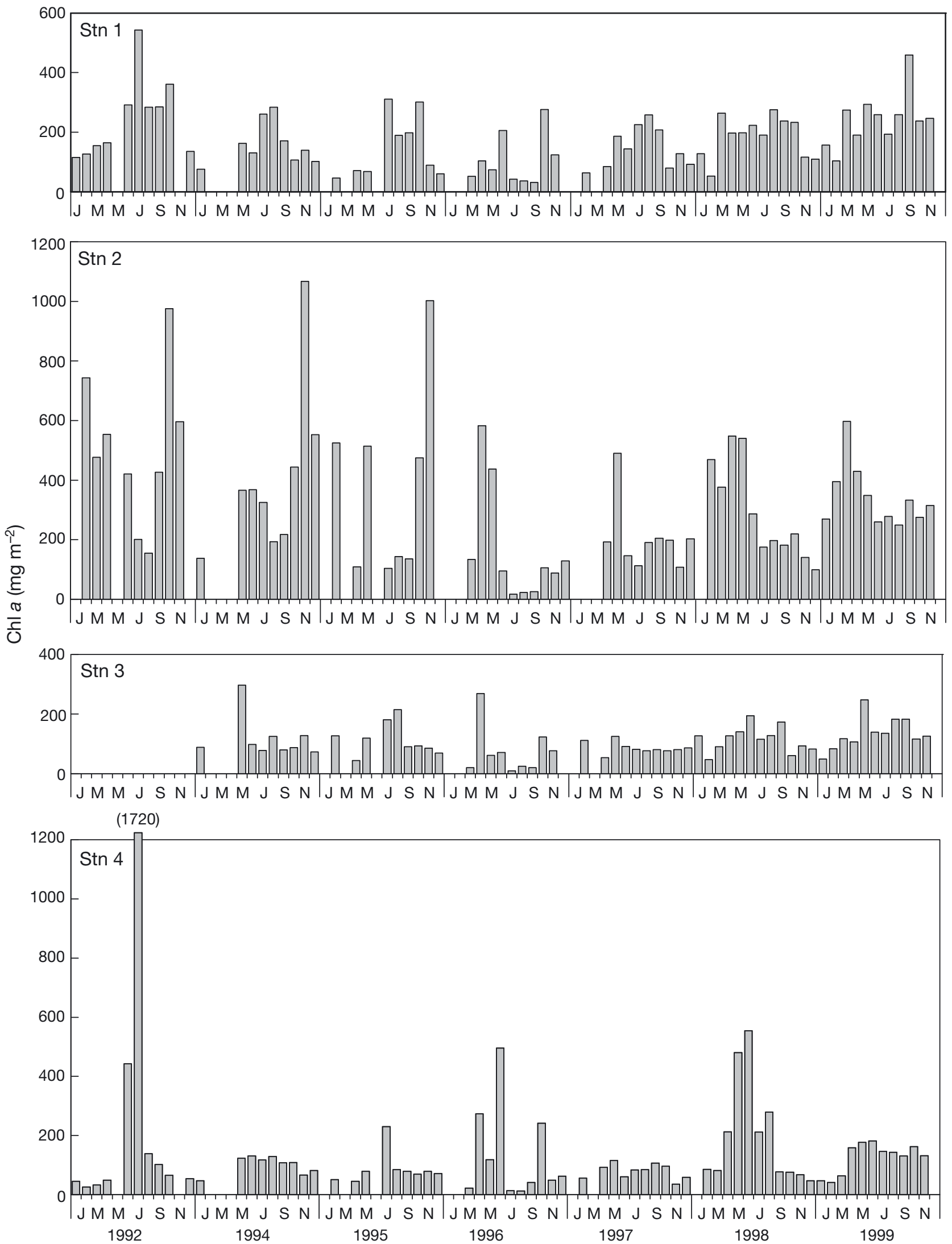

Fig. 3. Monthly fluctuations of chlorophyll a ( $\mathrm{chl} \mathrm{a}$ ) concentrations in the top sediment layer $(0.0-0.5 \mathrm{~cm})$ for the 6 stations for 1992, and 1994-1999, $\mathrm{n}=406$. Data from 1993 is missing. Missing bars indicate missing values 


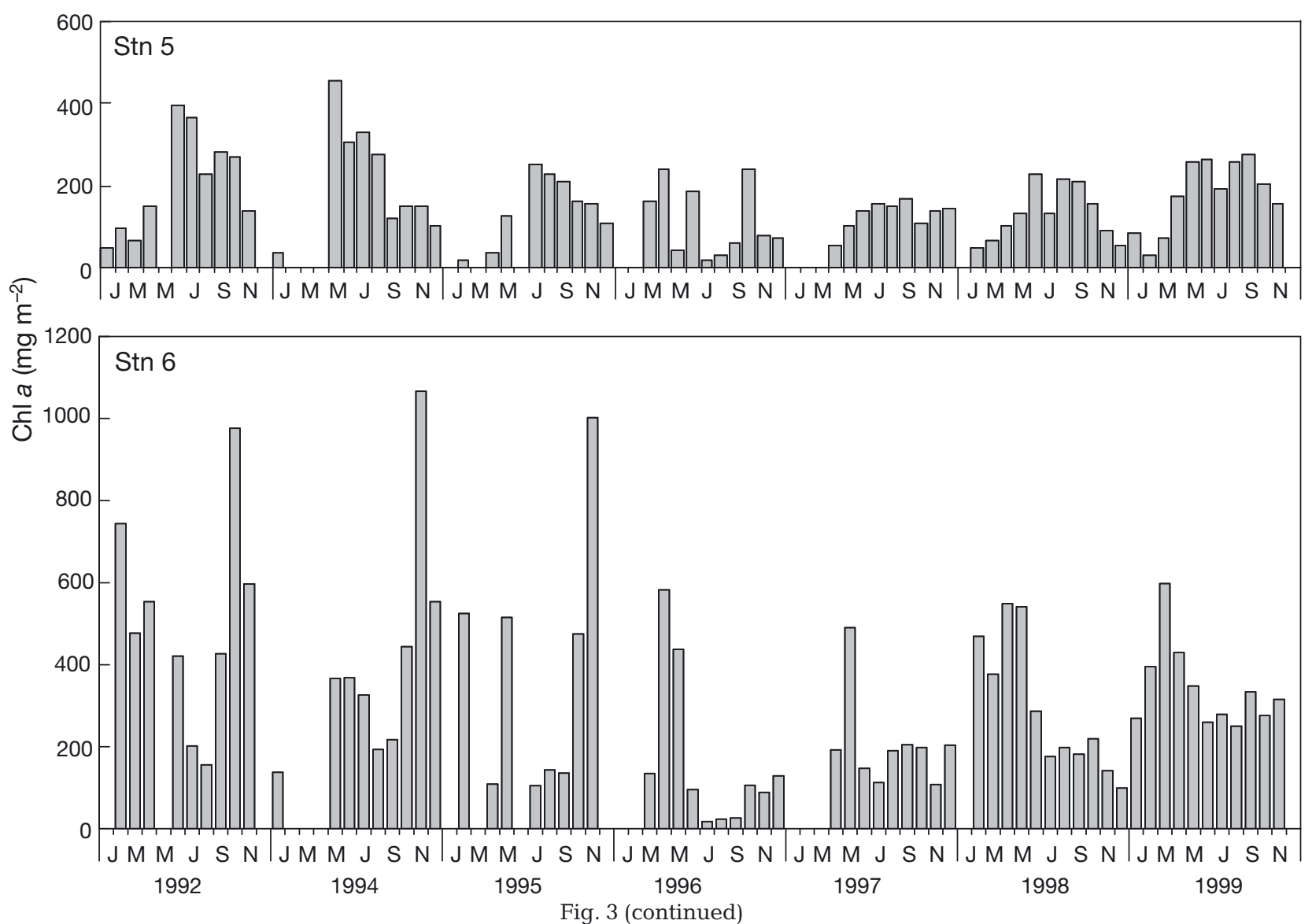

tion were plotted as a time series (Fig. 4). The values of all Stns decreased from 1992 to 1996, after which they increased again. Fig. 4 (see also the estuarywide annual means in Fig. 6) illustrates that there was no overall increasing or decreasing temporal trend in chl a during 1992, and 1994 to 1999. Given the fact that the individual sampling stations are located in the $\sim 50 \mathrm{~km}$ long main part of the estuary (Fig. 1) and are situated far from each other (max. distance ca. $40 \mathrm{~km}$ ), it is clear that estuary-wide operating factors or processes must have been responsible for the observed interannual variations.

\section{Station exposure time}

The highest elevated station was Stn 6, and the lowest were Stns 2, 3 and 4. The maximal difference in elevation was $2.3 \mathrm{~m}$ which, compared to the local tidal range of $\sim 3 \mathrm{~m}$, results in a large difference in exposure times among stations. Within some stations (thus among substations), the difference in elevation was also relatively large, e.g. at Stn 2 the difference between highest and lowest elevated substation was $1.0 \mathrm{~m}$. When averaged over all years, the log-transformed chl a concentrations of all 18 substations were significantly and positively correlated with the average exposure time (Fig. 5; GLM: $F_{1,17}=33.774, p<0.001$ ), explaining $68 \%$ of the total variation. This suggests that exposure time related factors like irradiance, wind speed and air temperature might also be candidate factors, explaining a part of the differences in chl a concentrations among stations.

Table 2. Three-way ANOVA with factors 'Yr', 'Location', and ' $\mathrm{Mo}$ ' on the mean monthly log-transformed chl a data per Stn (data set 1c in Table 1). The partial $\eta^{2}$-statistic is a relative index for the amount of variation that is attributable to a specific predictor variable

\begin{tabular}{|lrrrc|}
\hline Factor & $F$ & df & $p$ & $\eta^{2}$ \\
\hline Yr & 60.131 & 6,245 & $<0.001$ & 0.596 \\
Location & 44.427 & 4,245 & $<0.001$ & 0.476 \\
Mo & 12.133 & 11,245 & $<0.001$ & 0.353 \\
Yr $\times$ Location & 1.602 & 29,245 & $<0.05$ & 0.159 \\
Mo $\times$ Location & 3.344 & 55,245 & $<0.001$ & 0.429 \\
Yr $\times$ Mo & 6.707 & 55,245 & $<0.001$ & 0.601 \\
\hline
\end{tabular}




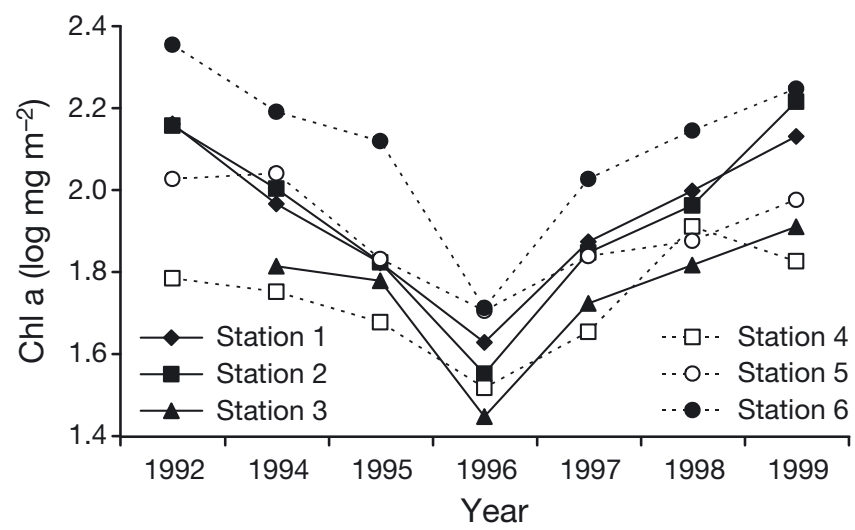

Fig. 4. Interannual variation of $\mathrm{chl}$ a concentration per $\mathrm{m}^{2}$ in the top layer of the sediment $(0.0-0.5 \mathrm{~cm})$ for the 6 stations sampled for 1992, and 1994-1999

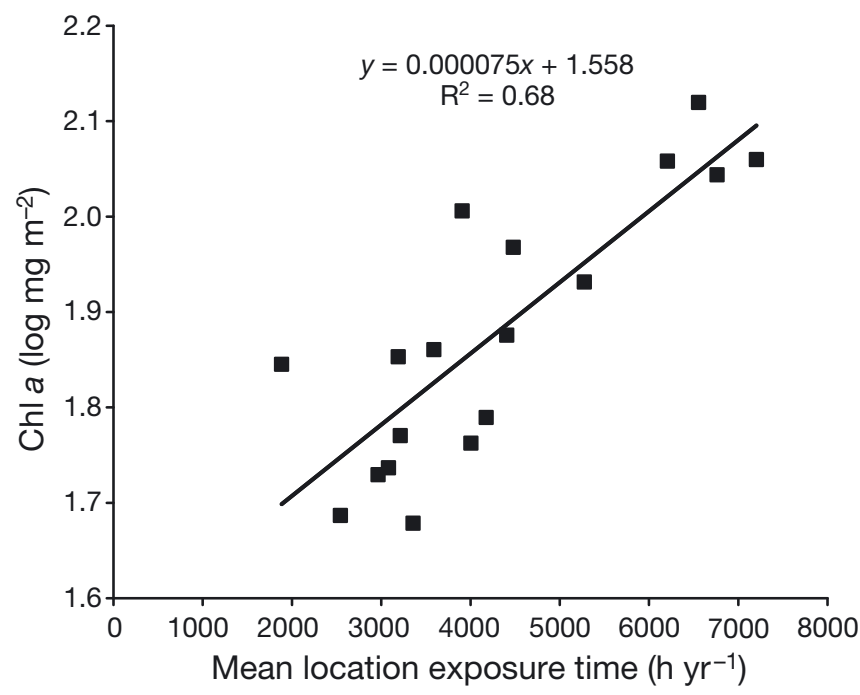

Fig. 5. Log-transformed total averaged chl a concentrations (per $0.5 \mathrm{~cm}$ sediment layer and $\mathrm{m}^{2}$ ) per sampled substation against the mean annual exposure time for 1994-1999 ( 3 substations per sampling station)

\section{Effect of physical factors}

Using the monthly mean chl a values, we tested for the influence of air temperature $(T)$, irradiance, suspended matter and wind speed, using the non-parametric Spearman rank correlation test (Table 3). All the presented correlations were highly significant. As expected, chl a values were positively related to $T$ and irradiance and negatively to wind speed and suspended matter, with the highest rank correlation coefficient for $T\left(\mathrm{r}_{\mathrm{S}}=0.55\right)$. These independent factors strongly co-vary, and a backward multiple regression only maintained $T$ as the single significant factor in the model $(t=3.189, \mathrm{n}=73, \mathrm{p}<0.01)$. A hierarchical partitioning confirmed this pattern, as the independent contribution of $T$ to the total explained
Table 3. Spearman correlation results $\left(\mathrm{r}_{\mathrm{S}}\right)$ between the mean monthly estuary-wide chl a concentrations $\left(\log \mathrm{mg} \mathrm{m}^{-2}\right.$ ) and the abiotic variables. The meteorological data are obtained from the Royal Netherlands Meteorological Institute (number of mean monthly values, $\mathrm{n}=73$ ), and the water quality data from Rijkswaterstaat (DONAR-database $\left.{ }^{b}\right)(n=69)$. The analyses are based on the data from 1992 and 1994-1999. Data are based on the estuary-wide mean chl a values in Table 1, data set 1c

\begin{tabular}{|c|c|c|}
\hline Variable & $\mathrm{r}_{\mathrm{S}}$ & $\mathrm{p}$ \\
\hline Air temperature $\left({ }^{\circ} \mathrm{C}\right)$ & 0.553 & $<0.001$ \\
\hline $\begin{array}{l}\text { Monthly \% of days with mean } \\
\text { daily air temperature }>0^{\circ} \mathrm{C}\end{array}$ & 0.498 & $<0.001$ \\
\hline Irradiance $\left(\mathrm{J} \mathrm{cm}^{-2}\right)$ & 0.440 & $<0.001$ \\
\hline $\begin{array}{l}\text { Monthly \% of days with maximum } \\
\text { hourly mean wind speed }>10 \mathrm{~m} \mathrm{~s}^{-1}\end{array}$ & -0.302 & $<0.001$ \\
\hline Suspended matter $\left(\mathrm{mg} \mathrm{l}^{-1}\right)$ & -0.317 & $<0.001$ \\
\hline
\end{tabular}

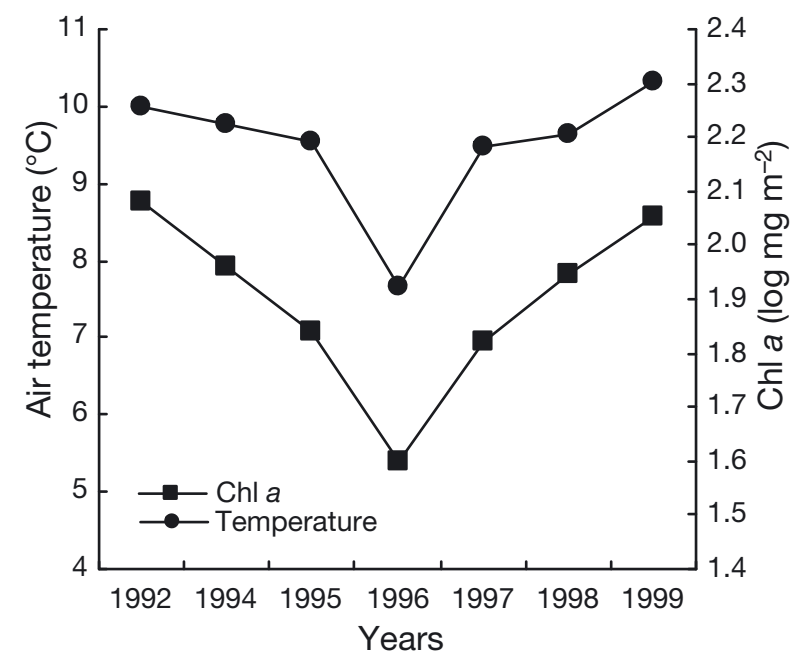

Fig. 6. Time series of the mean annual air temperatures (T) $\left({ }^{\circ} \mathrm{C}\right)$ and the estuary-wide averaged annual mean chl $a$ concentrations (log $\mathrm{mg} \mathrm{m}^{-2}$ ) for 1992, and 1994-1999. Concentrations expressed per $0.5 \mathrm{~cm}$ sediment layer

variance was larger than that of the other 4 variables combined (respectively 0.074 and $0.064 \%$ ).

Supported by the above analyses, a plot representing the time series of the mean annual $T$ and the mean log-transformed annual chl a values for 1992, and 1994 to 1999 was made (Fig. 6). The parallel trends in chl $a$ and $T$ of both curves are obvious, with a good correlation between chl $a$ and $T$. This resulted in the decision to extend the 1992, 1994 to 1999 data sets with older data for a more thorough analysis of the correlation between mean $T$ and estuary-wide mean annual chl a levels.

The mean annual chl $a$ values for the period 1976 to 1999 showed a strong positive effect of the mean 


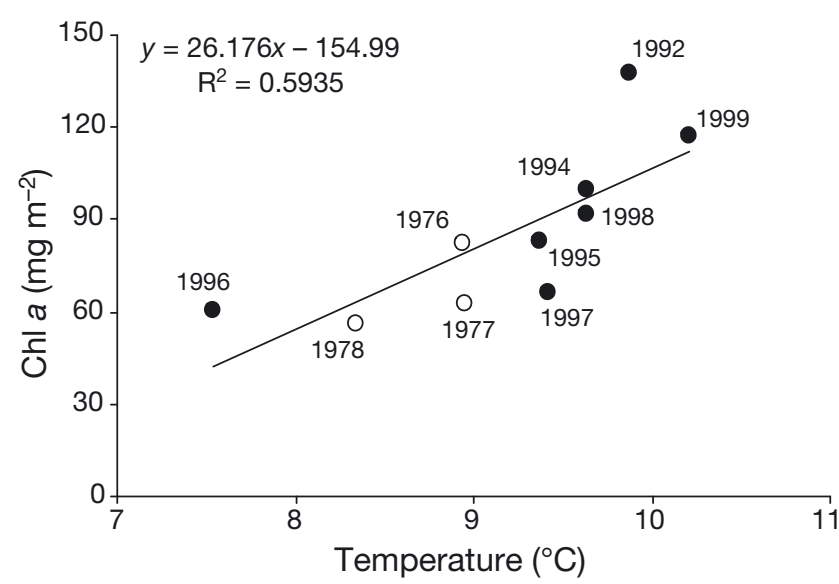

Fig. 7. Mean annual concentrations of estuary-wide averaged chl a against the mean annual air temperature $(T)$. Concentrations expressed per $0.5 \mathrm{~cm}$ sediment layer. 1992, 1994-1999 series, O: 1976-1978 data taken from the literature (Table 4)

annual $T$ (Fig. 7 ; GLM: $F_{1,10}=14.157 ; \mathrm{p}=0.004 ;$ based on data set 2 in Table 1, see also Table 4). Despite the relatively small range in the annual mean values $(7.5$ to $10.2^{\circ} \mathrm{C}$ ), the explained variance is relatively high, amounting to nearly $60 \%$. The lowest mean chl a value in the temperature range is 56.2 (1978) and the

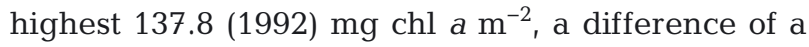
factor of $\sim 2.5$. To demonstrate that this picture is not biased by extending the original 1992, 1994 to 1999 data set with the older data, a separate regression for 1992, 1994 to 1999 was carried out as well. This latter analysis resulted in a similar fit $(y=23.14 x-123.51$ and $\mathrm{R}^{2}=0.53$ ).

Important to note is that there was no consistent difference between the $2 \mathrm{chl}$ a measurements methods (high performance liguid chromatography [HPLC] or spectrophotometric) in the $T$ and chl $a$ relationship (GLM, $\left.F_{1,9}=0.009, \mathrm{p}=0.925\right)$.

Table 4. Mean annual microphytobenthos chl a concentration and mean annual air temperatures $(T)$ from KNMI for the period 1976-1999. TE: total estuary

\begin{tabular}{|c|c|c|c|c|c|c|c|c|}
\hline \multirow[t]{2}{*}{ Year } & \multicolumn{6}{|c|}{ - Chlorophyll a $\left(\mathrm{mg} \mathrm{m}^{-2}\right)$} & \multirow[t]{2}{*}{$\mathrm{TE}$} & \multirow[t]{2}{*}{$\left({ }^{\circ} \mathrm{C}\right)$} \\
\hline & Stn 1 & Stn 2 & Stn 3 & $\operatorname{Stn} 4$ & Stn 5 & Stn 6 & & \\
\hline $1976^{\mathrm{a}}$ & 41.5 & 35.2 & 44.2 & 52.9 & 70.8 & 247.2 & 81.9 & 8.94 \\
\hline $1977^{a}$ & 60.2 & 33.2 & 50.2 & 33.2 & 73.6 & 124.0 & 62.3 & 8.95 \\
\hline $1978^{\mathrm{a}}$ & 32.6 & 28.6 & 41.9 & 34.5 & 71.9 & 128.0 & 56.2 & 8.34 \\
\hline $1992^{b}$ & 128.3 & 175.7 & 59.6 & 124.7 & 103.4 & 235.2 & 137.9 & 9.88 \\
\hline $1994^{\mathrm{b}}$ & 79.7 & 98.0 & 58.6 & 50.6 & 107.5 & 203.9 & 99.8 & 9.63 \\
\hline $1995^{\mathrm{b}}$ & 74.2 & 80.1 & 57.1 & 43.8 & 68.2 & 173.2 & 82.7 & 9.38 \\
\hline $1996^{\mathrm{b}}$ & 51.9 & 67.1 & 37.8 & 66.5 & 56.5 & 81.9 & 60.2 & 7.54 \\
\hline $1997^{b}$ & 73.5 & 74.2 & 43.3 & 39.5 & 64.4 & 102.5 & 66.2 & 9.42 \\
\hline $1998^{\mathrm{b}}$ & 92.8 & 92.8 & 57.5 & 94.2 & 65.1 & 147.0 & 91.5 & 9.63 \\
\hline $1999^{b}$ & 121.6 & 190.9 & 67.6 & 62.9 & 89.2 & 170.6 & 117.1 & 10.21 \\
\hline Dat & ado & $n \subset 8$ & liin & 24) & ctu & & & \\
\hline
\end{tabular}

\section{C:chl a ratios and temperature}

C:chl a ratios for 1976 and 1977 follow the temporal variation of the mean monthly $T$ (Fig. 8a). Data from 1978 was not incorporated in this analysis because it was too fragmented to represent either a reliable temporal variation or an appropriate annual average value (see de Jonge 1980 for further details).

Fig. $8 \mathrm{~b}$ shows a linear regression of the mean monthly C:chl $a$ ratios to the mean monthly $T$ over the same 2 yr $\left(y=1.28 x-29.94 ; G L M, F_{1,21}=12.568 ; \mathrm{p}=\right.$ $0.0019 ; 95 \% \mathrm{CI}$ for the regression coefficient: $0.53-$ 2.03 ; based on data set 3 in Table 1). Although the regression is significant, the relatively low explained variance of $37 \%$ indicates that factors other than temperature are also responsible for explaining the observed variation in $\mathrm{C}$ :chl a ratios.

\section{DISCUSSION}

\section{Annual variations in benthic chl a}

Causes for the large observed variation in the mean annual benthic chl a concentrations are typically grazing, resources and other environmental factors, as investigated here. The observed temperature related interannual variations are so strong (ca. 2.5fold) that a combination of $>1$ temperature related effect is likely and, thus, should to be considered.

It is not likely that nutrients played a major role, or that the water residence time in the system had changed. Thus, in case of the Ems estuary, other factors must be used to explain the major variations. These are temperature (Martens 2001, van Beusekom et al. 2009, present study), and light climate related factors caused by wind related turbidity changes (de Jonge 1995a), dredging activities (de Jonge 1983, 2000) and harbour spoil disposal (de Jonge \& de Jong 2002).

Despite the fact that we have not been able to investigate the role of grazers due to lack of data, it is likely that grazers controlled the interannual chl a variations as well (e.g. Alpine \& Cloern 1992, Hansen et al. 1993, Keller et al. 1999, Herman et al. 2000, Middelburg et al. 2000, Loebl \& van Beusekom 2008). These factors will be discussed in some detail below in the section 'Temperature, macrozooobenthos and carnivores'. 

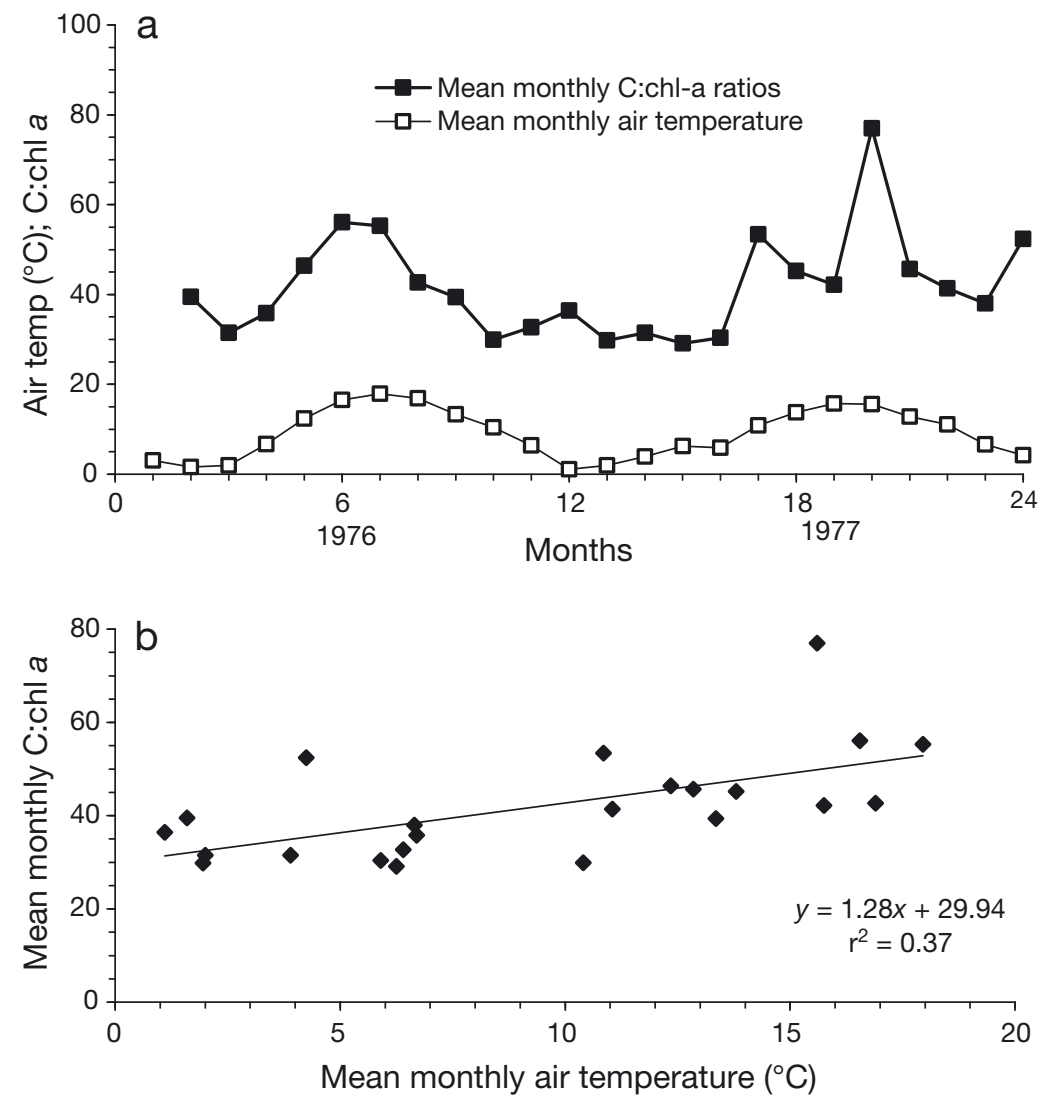

Fig. 8. (a) Time series of mean monthly C:chl a ratios ( $\square$ ) and mean monthly air temperature $(T)(\square)$ for 1976 and 1977. (b) Mean monthly C:chl a ratios against mean monthly $T$ for 1976 and 1977

Temperature and microphytobenthos

In relatively turbid systems like the Ems Estuary, intertidal microphytobenthos is mainly photosynthetically active when low tides coincide with the daily photoperiod. This implies that the physiological functioning of these microalgae may indeed be more determined by the strongly fluctuating air temperatures and related water temperatures in the diatom films during exposure than the more stable water temperature, as measured in the main channels.

The periodic exposure which microphytobenthos experiences also implies that these microalgae need to be very well adapted to highly dynamic environments, where sometimes the sediment temperature in summer may increase by $4^{\circ} \mathrm{C} \mathrm{h}^{-1}$ (Harrison 1985). Blanchard et al. $(1997,2006)$ performed field experiments on the photosynthetic capacity (P) of microphytobenthos during different seasons and different temperature increase rates $(\mathrm{T})$ and observed invariable $\mathrm{P}-\mathrm{T}$ curves over the year. The optimum temperature for photosynthesis was found at $25^{\circ} \mathrm{C}$, while a complete stop was measured at $38^{\circ} \mathrm{C}$. These results may be used as an indication of the short-term chl a response of the microphytobenthos to temperature. Despite the very high local chl a values at times (Fig. 3), this may imply that there is the possibility for some further increase in chl a levels. However, loss terms such as respiration, grazing and resuspension (de Jonge 1995a, Guarini et al. 2006) and gain terms such as (strong local) sedimentation of wind-wave induced resuspended microphytobenthos (de Jonge 1995a) also determine if and when an increase in primary production is reflected in an increase in biomass. Thus, there is most likely a limit to the (future) development of the benthic chl a concentration which is caused by algal density related growth limitation (Blanchard et al. 2001, 2002, 2006, Herlory et al. 2004).

The above-mentioned maximum amount of chl a of $\sim 160$ to $170 \mathrm{mg} \mathrm{m}^{-2}$ chl a (expressed by Blanchard and coworkers for their sampled $1 \mathrm{~cm}$ sediment layer, which corresponds to $\sim 120$ to $200 \mathrm{mg} \mathrm{m}^{-2} \mathrm{chl}$ a for the top $0.5 \mathrm{~cm}$ sediment layer as sampled by de Jonge \& Colijn 1994) may be exceeded considerably and reach values as high as $500 \mathrm{mg} \mathrm{m}^{-2}$ chl a (Colijn \& de Jonge 1984, Cahoon 1999), while peak values can even reach $1000 \mathrm{mg} \mathrm{m}^{-2}$ (present study). These higher levels are not necessarily the result of higher production, but might be the result of the above mentioned accumulation due to sedimentation of microalgae since resuspended material is not deposited in a uniform fashion over the intertidal flats. Therefore, despite the linear regression presented in Fig. 7, we expect that the presented curve may bend to an upper saturation level, which may correspond with data as referred to above.

\section{Temperature, macrozooobenthos and carnivores}

Apart from influencing the microphytobenthos directly, the existing seasonal variations, interannual temperature variations and cold winters may also indirectly affect the chl a mass via influencing the behaviour, growth and reproduction of macrozoobenthos species like the cockle Cerastoderma edule, 
the gaper clam Mya arenaria, the blue mussel Mytilus edulis and the Baltic tellin Macoma balthica (Beukema 1985, Beukema et al. 2001, Strasser et al. 2001, Beukema \& Dekker 2005) and epifauna like the brown shrimp Crangon crangon (Beukema 1992, Jönsson et al. 1993, Strasser, 2002). Moreover, it is possible that what has been found here for the above species also holds for other benthic species like the mud shrimp Corophium volutator, the mud snail Hydrobia ulvae and the lug worm Arenicola marina. This point is very relevant as the above mentioned macrozoobenthos species are not evenly distributed over the Ems estuary. If the varying chl a masses of the microphytobenthos could be clearly related to variations in grazing pressure and related resuspension stimulating activity of epifauna (e.g. Crangon crangon, Corophium volutator) or macrozoobenthos, then we should have an important explanation for both the short-term and the long-term variations in the benthic and resuspended chl a mass.

Turbidity and light

Based on in situ measurements in the lower reaches of the Ems estuary, Colijn (1983) showed that during high tide the microphytobenthos production can benefit from clear water. He determined that this effect could increase the annual microphytobenthos production (and consequently the chl a concentrations) by $\sim 35 \%$, compared to a situation where the primary production only occurred during exposure of the same area. Despite this finding, the average water turbidity in our analysis was only a weak predictor for explaining the monthly variation in chl a concentrations. This is remarkable because apart from the reported wind driven natural variation in SPM concentrations (de Jonge 1995a, 2000, de Jonge \& van Beusekom 1995), there is also a major (since 1970s) anthropogenic component in this estuary caused by channel maintenance dredging, the disposal of harbour sludge (de Jonge 1983) and major engineering works in the freshwater tidal river Ems itself since the mid 1980s with significant implications for the entire system (Schuttelaars et al. 2012). The result of the dredging activities was a $\sim 2-$ to 3 fold SPM increase in the main channels of the main estuary during the early 1990s compared to 1954, and of which the effects are also measurable during high water above the submerged intertidal flats (de Jonge 1995a, de Jonge \& van Beusekom 1995). If increased SPM affected microphytobenthos chl a, then one would have expected 2 independent regression lines in Fig. 7, one for the 1970s to 1980s and one for the 1990s. This is clearly not the case and effects of increased SPM on microphytobenthos chl a concentrations, even in the lower reaches of the intertidal flats (Stn 1), can most likely be excluded.

\section{Wind-induced resuspension}

The resuspension of microphytobenthos into the water column is an important process determining the microphytobenthos chl a distribution between the intertidal flats and the water column (de Jonge \& van Beusekom 1995, Koh et al. 2006). Due to windy, but not necessarily stormy, conditions a significant part of the microphytobenthos is resuspended into the water column where it continues to grow like phytoplankton (V. N. de Jonge \& H. Peletier unpubl. experimental results). Under normal weather conditions, only 25\% of the total microphytobenthos chl $a$ is present in the water column in this estuary (de Jonge 1995a). Under strong winds conditions (e.g. $12 \mathrm{~m} \mathrm{~s}^{-1}$ wind speed), this value only doubles (de Jonge \& van Beusekom 1995). Within the context of this paper, the effect of wind on resuspension is not strong enough to account for the 2.5-fold variation observed in the benthic chl a.

\section{C:chl a ratios}

In the literature, chl $a$ is often considered a suitable proxy for algal biomass, but this assumption is not correct. In the late 1970s (de Jonge 1980), a significant (up to an order of magnitude) temporal variation in $\mathrm{C}$ :chl a ratios was measured. Consequently, algal biomass cannot simply be calculated from chl a values through linear transformation, nor can chl a values be directly converted into carbon biomass by using a constant (mean annual) C:chl a ratio. Thus, it is of importance to verify whether there is a possible amplification of the temperature effect on chl a by an additional effect via the $\mathrm{C}$ :chl a ratio. When using seasonal data, this is indeed the case, but the seasonal temperature effect on the $\mathrm{C}$ :chl a ratio is so modest (only $3 \%$ increase per $1^{\circ} \mathrm{C}$ air temperature; Fig. $8 \mathrm{~b}$ ) that the ultimate effect on the carbon biomass is considered to be marginal compared to the direct effect on chl a.

\section{Future estuarine functioning}

When the findings and suggestions by Martens (2001) and van Beusekom et al. (2009) for the List 
tidal basin (German Wadden Sea) are combined with a part of our results for the Ems estuary, it may be that an overall increase in temperature may lead to a decrease in the spring bloom of the phytoplankton and to an increase in the benthic microphytobenthos biomass. Due to wind-induced resuspension of the microphytobenthos (de Jonge 1995a, de Jonge \& van Beusekom 1995), an increase in the benthic biomass will consequently lead to an increase of microphytobenthos in the water column, therefore, the proportion between resuspended microphytobenthos chl $a$ and that of phytoplankton will increase. This suggests that if the average temperatures or the water turbidity further increase, a gradual shift may occur in the relative importance of primary production from phytoplankton to microphytobenthos. However, based on the observations and calculations by Blanchard et al. (2001, 2002, 2006, Herlory et al. 2004), there is most likely a limit to this development by algal density related growth limitation.

The functioning of the phytoplankton is further dependent on water temperature and favourable turbidity and light conditions, while the microphytobenthos is more dependent on suitable growth conditions governed by favourable weather conditions. How this under the current human pressures (e.g. dredging and engineering works) and climate change related developments may work out in the future and also in systems with a lower turbidity than the Ems estuary is not clear and needs further research.

Additionally, the reproduction of autochthonous grazers and their carnivores, and also invaders like the rapidly developing bivalve Crassostrea gigas (Buschbaum et al. 2011), may be affected by changing temperatures. How this potential effect modifies the food web and, thus, the functioning of both the pelagic as well as the benthic system in the Wadden Sea needs further attention.

Despite the integrative modelling exercise carried out for this estuary in the past (Baretta \& Ruardij 1988), it is still unclear how the above mentioned factors (temperature, light conditions, respiration, grazing and resuspension) interact on a more detailed level. Thus, there is an urgent need for an integrated approach to these issues in future studies.

In addition, we also need to give high priority to a clear coupling of strongly improved monitoring programs and further development of ecosystem models (de Jonge et al. 2006), because microphytobenthos is much more important for coastal areas than generally recognized.

\section{CONCLUSIONS}

This long-term study produced two major conclusions: (1) The microphytobenthos in the Ems estuary shows a strong positive response to temperature, a 2.5-fold variation in the mean annual chl a concentrations within a mean annual range in air temperature of 7.5 to $10.2^{\circ} \mathrm{C}$ and (2) the remarkably strong interannual response of microphytobenthos chl a to temperature seems only explainable from a combination of factors that, apart from direct 'bottom-up' temperature effects to the algae (e.g. C:chl $a$ and unmeasured algal activity) also comprise temperature related variations in 'top-down' control via grazers and even their carnivores.

Acknowledgements. V. N. de Jonge acknowledges 'The Water Service' (Waterdienst) of Rijkswaterstaat for its continuous financial support and interest in the research results and $\mathrm{H}$. de Knegt for his assistance with calculating the spatial autocorrelation.

\section{LITERATURE CITED}

Admiraal W (1977a) Influence of various concentrations of orthophosphate on the division rate of an estuarine benthic diatom, Navicula arenaria in culture. Mar Biol 42: $1-8$

Admiraal W (1977b) Influence of light and temperature on the growth rate of estuarine benthic diatoms in culture. Mar Biol 39:1-9

Admiraal W, Peletier H (1980) Influence of seasonal variations of temperature and light on the growth rate of cultures and natural populations of intertidal diatoms. Mar Ecol Prog Ser 2:35-43

Admiraal W, Peletier H, Zomer H (1982) Observations and experiments on the population dynamics of epipelic diatoms from an estuarine mudflat. Estuar Coast Shelf Sci 14:471-487

> Alpine AE, Cloern JE (1992) Trophic interactions and direct physical effects control phytoplankton biomass and production in an estuary. Limnol Oceanogr 37:946-955

> Baird D, Asmus H, Asmus R (2004) Energy flow of a boreal intertidal ecosystem, the Sylt Rømø Bight. Mar Ecol Prog Ser 279:45-61

Baretta JW, Ruardij P (eds) (1988) Tidal flat estuaries: simulation and analysis of the Ems Estuary. Ecological Studies 71, Springer, Heidelberg, p 353

Barranguet C, Kromkamp J, Peene J (1998) Factors controlling primary production and photosynthetic characteristics of intertidal microphytobenthos. Mar Ecol Prog Ser 173:117-126

Beukema JJ (1985) Zoobenthos survival during severe winters on high and low tidal flats in the Dutch Wadden Sea. In: Gray JS, Christiansen ME (eds) Marine biology of polar regions and effects of stress on marine organisms. John Wiley, Chichester, p 351-361

Beukema JJ (1992) Dynamics of juvenile shrimp Crangon crangon in a tidal-flat nursery of the Wadden Sea after mild and cold winters. Mar Ecol Prog Ser 83:157-165 
Beukema JJ, Dekker R (2005) Decline of recruitment success in cockles and other bivalves in the Wadden Sea: possible role of climate change, predation on postlarvae and fisheries. Mar Ecol Prog Ser 287:149-167

> Beukema JJ, Dekker R, Essink K, Michaelis H (2001) Synchronized reproductive success of the main bivalve species in the Wadden Sea: causes and consequences. Mar Ecol Prog Ser 211:143-155

> Blanchard GF, Guarini JM, Richard P, Gros Ph (1997) Seasonal effect on the relationship between the photosynthetic capacity of intertidal microphytobenthos and short-term temperature changes. J Phycol 33:723-728

> Blanchard GF, Guarini JM, Orvain F, Sauriau PG (2001) Dynamic behaviour of benthic microalgal biomass in intertidal mudflats. J Exp Mar Biol Ecol 264:85-100

Blanchard GF, Simon-Bouhet B, Guarini JM (2002) Properties of the dynamics of intertidal microphytobenthic biomass. J Mar Biol Assoc UK 82:1027-1028

Blanchard GF, Agion T, Guarini JM, Herlory O, Richard P (2006) Analysis of the short-term dynamics of microphytobenthos biomass on intertidal mudflats. Koninklijke Nederlandse Akademie van Wetenschappen, Verhandelingen, Afd. Natuurkunde, Tweede Reeks, Part 103, p 85-97

> Brotas V, Cabrita T, Portugal A, Serôdio J, Catarino F (1995) Spatio-temporal distribution of the microphytobenthic biomass in intertidal flats of Tagus Estuary (Portugal). Hydrobiologia 300-301:93-104

Buschbaum C, Lackschewitz D, Reise K (2011) Nonnative macrobenthos in the Wadden Sea ecosystem. Ocean Coast Manage doi:10.1016/j.ocecoaman.2011.12.011

Cahoon LB (1999) The role of benthic microalgae in neritic ecosystems. Oceanogr Mar Biol Annu Rev 37:47-86

Cahoon LB (2006) Upscaling primary production estimates: Regional and global scale estimates of microphytobenthos production. In: Kromkamp JC, de Brouwer JFC, Blanchard GF, Forster RM, Créach V (eds) Functioning of microphytobenthos in estuaries. Koninklijke Nederlandse Akademie van Wetenschappen, Verhandelingen, Afd. Natuurkunde, Tweede Reeks, Part 103, p 99-108

Chevan A, Sutherland M (1991) Hierarchical partitioning. Am Stat 45:90-96

$>$ Colijn F (1982) Light absorption in the waters of the EmsDollard estuary and its consequences for the growth of phytoplankton and microphytobenthos. Neth J Sea Res 15:196-216

Colijn F (1983) Primary production in the Ems-Dollard estuary. PhD thesis, University of Groningen, p 123

Colijn F, de Jonge VN (1984) Primary production of microphytobenthos in the Ems-Dollard estuary. Mar Ecol Prog Ser 14:185-196

Colijn F, van Buurt G (1975) Influence of light and temperature on the photosynthetic rate of marine benthic diatoms. Mar Biol 31:209-214

> Cook PLM, Holland DP, Longmore AR (2010) Effect of a flood event on the dynamics of phytoplankton and biogeochemistry in a large temperate Australian lagoon. Limnol Oceanogr 55:1123-1133

> Daemen EAJM (1986) Comparison of methods for the determination of chlorophyll in estuarine sediments. Neth $\mathrm{J}$ Sea Res 20:21-28

de Jonge VN (1980) Fluctuations in the organic carbon to chlorophyll a ratios for estuarine benthic diatom populations. Mar Ecol Prog Ser 2:345-353

de Jonge VN (1983) Relations between annual dredging activities, suspended matter concentrations, and the development of the tidal regime in the Ems estuary. Can J Fish Aquat Sci 40(Suppl 1):s289-s300

> de Jonge VN (1985) The occurrence of 'epipsammic' diatom populations: a result of interaction between physical sorting of sediment and certain properties of diatom species. Estuar Coast Shelf Sci 21:607-622

> de Jonge VN (1992a) Tidal flow and residual flow in the Ems estuary. Estuar Coast Shelf Sci 34:1-22

de Jonge VN (1992b) Physical processes and dynamics of microphytobenthos in the Ems estuary (the Netherlands). PhD thesis. Rijksuniversiteit Groningen

de Jonge VN (1995a) Wind driven tidal and annual gross transports of mud and microphytobenthos in the Ems estuary, and its importance for the ecosystem. In: Dyer KR, D'Elia CF (eds) Changes in fluxes in estuaries. Olsen \& Olsen, Fredensborg, p 29-40

de Jonge VN (1995b) The Ems Estuary. A case study. In: McComb AJ (ed) Eutrophic shallow estuaries and lagoons. CRC-Series, CRC Press, Boca Raton, p 81-107

de Jonge VN (2000) Importance of temporal and spatial scales in applying biological and physical process knowledge in coastal management, an example for the Ems estuary. Cont Shelf Res 20:1655-1686

de Jonge VN, Colijn F (1994) Dynamics of microphytobenthos biomass in the Ems estuary measured as chlorophyll $a$ and carbon. Mar Ecol Prog Ser 104:185-196

> de Jonge VN, de Jong DJ (2002) 'Global Change' impact of inter-annual variation in water discharge as a driving factor to dredging and spoil disposal in the river Rhine system and of turbidity in the Wadden Sea. Estuar Coast Shelf Sci 55:969-991

de Jonge VN, Essink K (1991) Long-term changes in nutrient loads and primary production in the Dutch Wadden Sea. In: Elliott M, Ducrotoy JP (eds) Estuaries and coasts: spatial and temporal intercomparisons. Olsen \& Olsen International Symposium Series, Fredensborg, p 307-316

de Jonge VN, van Beusekom JEE (1992) Contribution of resuspended microphytobenthos to total phytoplankton in the Ems estuary and its possible role for grazers. Neth J Sea Res 30:91-105

> de Jonge VN, van Beusekom JEE (1995) Wind and tide induced resuspension of sediment and microphytobenthos from tidal flats in the Ems estuary. Limnol Oceanogr 40:776-778

> de Jonge VN, Elliott M, Brauer VS (2006) Marine monitoring: its shortcomings and mismatch with the EU Water Framework Directive's objectives. Mar Pollut Bull 53: 5-19

$>$ Decho AW, Fleeger JW (1988) Microscale dispersion of meiobenthic copepods in response to food-resource patchiness. J Exp Mar Biol Ecol 118:229-243

Guarini JM, Blanchard GF, Richard P (2006) Modelling the dynamics of the microphytobenthic biomass and primary production in European intertidal mudflats. In: Kromkamp JC, de Brouwer JFC, Blanchard, Forster RM, Créach V (eds) Functioning of microphytobenthos in estuaries. Koninklijke Nederlandse Akademie van Wetenschappen, Verhandelingen, Afd. Natuurkunde, Tweede Reeks, Part 103, p 187-226

Hansen FC, Reckermann M, Klein Breteler WCM, Riegman R (1993) Phaeocystis blooming enhanced by copepod predation on protozoa: evidence from incubation experiments. Mar Ecol Prog Ser 102:51-57 
Harrison S (1985) Heat exchanges in muddy intertidal sediments: Chicester harbour, west Sussex, England. Estuar Coast Shelf Sci 20:477-490

Hecky RE, Hesslein RH (1995) Contributions of benthic algae to lake food webs as revealed by stable isotope analysis. J N Am Benthol Soc 14:631-653

Helder W (1983) Aspects of the nitrogen cycle in Wadden Sea and Ems-Dollard estuary with emphasis on nitrification. PhD thesis, University of Groningen

Helder W, Ruardij P (1982) A one-dimensional mixing and flushing model of the Ems-Dollart estuary: calculation of time scales at different river discharges. Neth J Sea Res 15:293-312

Herlory O, Guarini JM, Richard P, Blanchard GF (2004) Microstructure of microphytobenthic biofilm and its spatio-temporal dynamics in an intertidal mudflat (Aiguillon Bay, France). Mar Ecol Prog Ser 282:33-44

> Herman PMJ, Middelburg JJ, Widdows J, Lucas CH, Heip CHR (2000) Stable isotopes as trophic tracers: combining field sampling and manipulative labelling of food resources for macrobenthos. Mar Ecol Prog Ser 204:79-92

- Hummel H (1985) Food intake of Macoma balthica (Mollusca) in relation to seasonal changes in its potential food on a tidal flat in the Dutch Wadden Sea. Neth J Sea Res 19:52-76

Jong DJ, Nienhuis PH, Kater BJ (1994) Microphytobenthos in the Oosterschelde Estuary (The Netherlands), 19811990: consequences of a changed tidal regime. Hydrobiologia 282-283:183-195

Jönsson B, Sundbäck K, Nilsson P, Nilsson C, Linström Swanberg I, Ekebom J (1993) Does the influence of the epibenthic predator Crangon crangon L. (brown shrimp) extend to sediment microalgae and bacteria? Neth J Sea Res 31:83-94

Kamermans P (1994) Similarity in food source and timing of feeding in deposit-and suspension-feeding bivalves. Mar Ecol Prog Ser 104:63-75

Keller AA, Oviatt CA, Walker HA, Hawk JD (1999) Predicted impacts of elevated temperature on the magnitude of the winter-spring phytoplankton bloom in temperate coastal waters: a mesocosm study. Limnol Oceanogr 44:344-356

Koh CH, Khim JS, Araki H, Yamanishi H, Mogi H, Koga K (2006) Tidal resuspension of microphytobenthic chlorophyll $a$ in a Nanaura mudflat, Saga, Ariake Sea, Japan: flood-ebb and spring-neap variations. Mar Ecol Prog Ser 312:85-100

Loebl M, van Beusekom JEE (2008) Seasonality of microzooplankton grazing in the northern Wadden Sea. J Sea Res 59:203-216

> Lorenzen CJ (1967) Determination of chlorophyll and pheopigments: spectrophotometric equations. Limnol Oceanogr 12:343-346

Editorial responsibility: Christine Paetzold, Oldendorf/Luhe, Germany
MacIntyre HL, Geider RJ, Miller DC (1996) Microphytobenthos: The ecological role of the 'secret garden' of unvegetated, shallow-water marine habitats. 1. Distribution, abundance and primary production. Estuaries 19: 186-201

Martens P (2001) Effects of the severe winter 1995/96 on the biological oceanography of the Sylt-Rømø tidal basin. Helgol Mar Res 55:166-169

> Middelburg JJ, Barranguet C, Boschker HTS, Herman PMJ, Moens T, Heip CHR (2000) The fate of intertidal microphytobenthos carbon: an in situ 13C labelling study. Limnol Oceanogr 45:1224-1234

> Moed JR, Hallegraeff GM (1978) Some problems in the estimation of chlorophyll a and pheo-pigments from pre- and post-acidification spectrophotometric measurements. Int Rev Gesamten Hydrobiol Hydrogr 63:787-800

> Moncreiff CA, Sullivan MJ (2001) Trophic importance of epiphytic algae in subtropical seagrass beds: Evidence from multiple stable isotope analyses. Mar Ecol Prog Ser 215:93-106

R Development Core Team (2007) R: a language and environment for statistical computing. Version 2.8.1 R Foundation for Statistical Computing, Vienna. www. R-project.org

Schuttelaars HM, de Jonge VN, Chernetsky A (2012) Improving the predictive power when modelling physical effects of human interventions in estuarine systems. Ocean Coast Manage. doi:10.1016/j.ocecoaman. 2012.05.009

Strasser M (2002) Reduced epibenthic predation on intertidal bivalves after a severe winter in the European Wadden Sea. Mar Ecol Prog Ser 241:113-123

> Strasser M, Hertlein A, Reise K (2001) Differential recruitment of bivalve species in the northern Wadden Sea after the severe winter of 1995/96 and of subsequent milder winters. Helgol Mar Res 55:182-189

> Underwood GJC, Kromkamp J (1999) Primary production by phytoplankton and microphytobenthos in estuaries. Adv Ecol Res 29:93-153

> van Beusekom JEE, de Jonge VN (1998) Retention of phosphorus and nitrogen in the Ems estuary. Estuaries 21: 527-539

> van Beusekom JEE, Loebl M, Martens P (2009) Distant riverine nutrient supply and local temperature drive the longterm phytoplankton development in a temperate coastal basin. J Sea Res 61:26-33

van Es FB (1982) Some aspects of the flow of oxygen and organic carbon in the Ems-Dollard estuary. PhD thesis. Rijksuniversiteit Groningen

> van Oldenborgh GJ, Drijfhout S, van Ulden A, Haarsma R and others (2008) Western Europe is warming much faster than expected. Clim Past Discuss 4:897-928

Zar JH (1984) Biostatistical analysis. Prentice Hall, London

Submitted: January 31, 2012; Accepted: July 24, 2012

Proofs received from author(s): November 2, 2012 